\title{
The Influence of Brand Awareness, Perceived Quality, Brand Association, Brand Loyalty on Brand Equity of Zakat Institutions
}

\author{
Muhammad Doddy ${ }^{1}$, Juhary $\mathrm{Ali}^{2}$, Anton Hindardjo ${ }^{3}$, Cicih Ratnasih ${ }^{4}$ \\ \{muhammad.doddy@sebi.ac.id ${ }^{1}$, juhary.ali@aeu.edu.my², anton.hindardjo@sebi.ac.id ${ }^{3}$, \\ cicih_ratnasih@borobudur.ac.id ${ }^{4}$ \}
}

Lecturer STEI SEBI, Indonesia and PhD Candidate of Asia e University Malaysia ${ }^{1}$, Professor of Asia e University Malaysia, Kuala Lumpur ${ }^{2}$, Lecturer STEI SEBI, Indonesia and PhD Candidate of Asia e University Malaysia, Professor of Universitas Borobudur, Jakarta, Indonesia ${ }^{4}$

\begin{abstract}
This study aims to examine how the influence, among others, brand image, perceived quality, brand loyalty to brand equity in a zakat institution. The research design used is descriptive and explanatory with a quantitative approach. The sample size is 375 zakat payers from a leading zakat institution in Greater Jakarta. The method of collecting data by distributing questionnaires was taken by clustered random sampling. Data processing used Partial Least Square SEM (PLS-SEM), where the results showed a significant influence between the variables of brand awareness, perceived quality, brand association, brand loyalty to brand equity. According to previous studies, brand loyalty has a dominant effect on brand equity as a whole. Zakat institutions must pay attention to the antecedents of brand equity in order to increase zakat fundraising.
\end{abstract}

Keywords: brand awareness, perceived quality, brand association, brand loyalty, brand equity.

\section{Introduction}

The scope for zakat funding in Indonesia is comparatively high as a mainly Muslim nation in South East Asia. However, only three percent of the zakat potential is the zakat that Zakat institutions can collect. According to BAZNAS, the zakat management situation nationally in Indonesia is 2.76 percent of the IDR 217 trillion (15 billion USD) capacity in 2017. In Indonesia, the potential for zakat funds is almost 3.4\% of the Gross Domestic Product. There are two zakat institutions responsible for managing, distributing, and utilizing zakat in Indonesia, namely the National Amil Zakat Agency (known as BAZNAS) and the Amil Zakat Institute (known as LAZ). The Amil Zakat Institution has risen recently in Indonesia. The emergence of various kinds of Amil Zakat Institutions is motivated by various antecedents, such as the excitement to raise awareness among Muslims, the spirit of establishing a professional zakat institution, and regulations that have begun to help the zakat management system in Indonesia. Recently, the Ministry of Religion of the Republic of Indonesia has registered 15 zakat institutions [1].

There is a growing competition among zakat institutions. Not only at single moments like Ramadan, is the promotion of zakat institutions carried out. Zakat institutions are being allowed to optimize their accomplishments by the rising number of middle classes in Indonesia. This opportunity is good because those institutions' efforts will help the Indonesians, especially the poor, distribute wealth. For zakat institutions, competition is a good thing. Zakat institutions will be pushed to develop their services by the competition between zakat institutions. Different developments have emerged in the field of zakat services, 
including zakat services, e-payments, and the provision of zakat consulting companies that facilitate the planning of Zakat payers [2].

Zakat institutions must be branded to provide the institution with added value and reinforce the institution's identity. Amil zakat institutions of public trust would find it easier to send zakat messages to zakat payers. Zakat institutions unable to create identities will get their customers' wrong impression and credibility. Brands thus shield organizations from the negative view of evil things by individuals. By branding, amil zakat institutions can provide muzakki with added value so that muzakki can pay more.

Therefore, this study aims to determine what influences the strength of brand equity in zakat institutions, which is driven by brand awareness, brand association, perceived quality, and brand loyalty.

\section{Literature Review}

In particular, in the 1980s, marketing and brand experts have researched brand equity [3] and produced various brand equity models [4]. Brand equity was first defined as the value transferred to products by a brand [5]. The definition of brand equity is then expanded to include the driving factors for brand equity based on consumer-based perceptions that show the value assigned to a product in its customers [6] [7]. Keller then supported this definition, who proposed a definition of brand equity based on consumer responses to brand marketing based on brand knowledge [8].

In the 2000s, Yoo et al. defined brand equity based on consumer decisions on the difference between branded and unbranded products [9]. Kotler et al. promote brand equity, as the added value provided to goods and services based on price, market share, or profitability, for buying decisions based on the value provided to a product. Finally, this term is more generally known as "customer-based brand equity," so customers understand an advertised product in current business practices. [10]. Cheng and Chan have divided the definition of customer-based brand equity. The first is based on consumer perception, including brand awareness, branding association, and perceived quality. Second, based on consumer behavior, including customer loyalty [11].

No consensus was found about the meaning of brand equity and its dimensions, and the term brand equity has various connotations [12], [13], [14], [15], [16], [17]. In measuring brand equity and building strong brands, brand experts have proposed various indirect models and measures, and these models consider it a multidimensional construct [6], [9], [10], [18], [19]. The brand equity model provided by Aaker has been predominantly used in the literature on consumer-based brand equity [19], [20]. It consists of brand awareness, perceived quality, brand association, and brand loyalty.

\subsection{Brand Awareness}

Shimp \& Andrews define that brand awareness is a brand that can be present in the minds of customers when they think about those product groups and how simple it is to say the name [21]. Brand awareness is one of the fundamental brand equity dimensions. Consumers are unaware of a brand's nature because the brand has little equity in the customer viewpoint. Brand awareness is the strength of the brand identity of the consumer, according to Aaker. The capacity of the customer to remember and store in its memory demonstrates this power [6]. 


\subsection{Brand Association}

According to Aaker, brand associations, which primarily form brand images, are the basis for consumer decision making to buy products or use services, and encourage brand loyalty [22]. According to Keller, brand association has several types. The first type is the attribute in which the brand association has a relationship with the brand attribute, whether it has a direct relationship with the product or not. The second type is a brand benefit where the brand association is associated with brand advantages, both functional advantage, and user experience. The third type is an attitude, where the brand association is associated with selfmotivation, forms of reward, punishment, knowledge, and learning [8].

\subsection{Perceived Quality}

According to Zeithaml, perceived quality is a consumer's perception of the overall quality or superiority of a product or service concerning its intended purpose and its relationship with other product alternatives. Perceived quality is a subjective consumer assessment of product dominance, consumption circumstances, and special needs that can influence subjective consumer quality assessments [23]. According to Aaker, positive quality impressions can be developed through efforts to identify the quality dimensions that customers consider essential (targeted market segments) and to establish quality perceptions of critical brand dimensions. [6].

Perceived quality is an overall service product that can determine the value of a product or service and directly influence consumer purchasing decisions and brand loyalty. If the consumer's opinion of quality is negative, the product will not be liked and will not last long. A product is preferred if the customer is supportive [24].

\subsection{Brand Loyalty}

One of the main elements of building brand equity is brand loyalty. This element is the main factor that creates customer-based brand equity because customers are loyal to their brand only in terms of satisfaction and complete trust [24]. According to Aaker, brand loyalty is based on the consistency of consumer behavior in buying a brand as a means of consumer learning about the brand's ability to meet its needs [22].

\section{Conceptual Model and Hypotheses Development}

\subsection{Conceptual Model}

Figure 1 describes the conceptual model that will be used in this study based on the framework proposed by Aaker [6]. Several variables are antecedents of brand equity, which will later be applied to zakat institutions. The brand equity of zakat institutions is influenced by brand awareness, brand association, perceived quality, and brand loyalty. All antecedentconsequence relationships need to be assessed for applying the concept of brand equity to zakat institutions. 


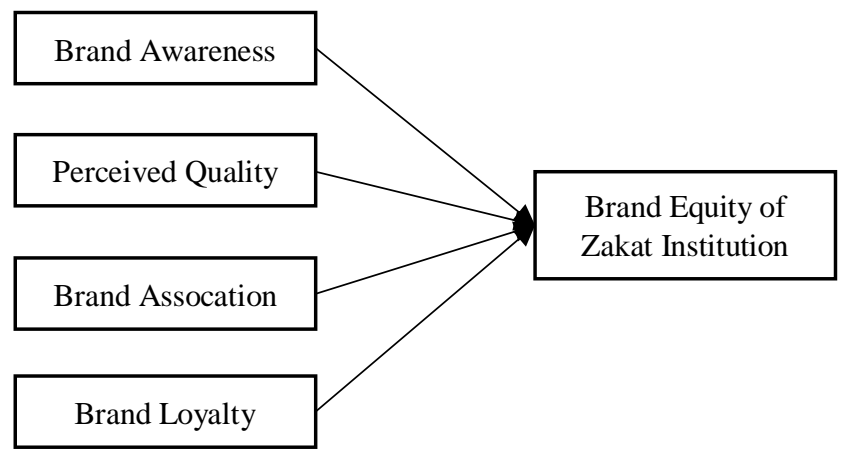

Fig. 1. Conceptual Model.

\subsection{Hypotheses Development}

From this conceptual model, several hypotheses will be made, which will later be tested whether the hypothesis has a significant effect. The following are some of the proposed hypotheses.

\subsubsection{Brand Awareness and Brand Equity}

Brand awareness is an initial prerequisite for creating brand equity [25] because consumers need to be aware that a brand exists. Brand awareness is a signal of how well consumers can recognize a brand and remember it [26]. Previous studies have shown that brand associations are shown to significantly contribute to consumer decision making [27] and generate customer-based brand equity [6]. Customers were found to buy these brands, which they could identify [28], and awareness signifies reputation and familiarity [29]. Researchers considered brand awareness an integral brand equity dimension [12], [29], [18], [30], [31], [32]. Thus, the following hypothesis is formulated:

H1: Brand awareness has a significant direct effect on brand equity of zakat instituion.

\subsubsection{Perceived quality dan Ekuitas Merek}

Perceived quality is the advantage of an offer from a product or service [23], [25]. Perceptions of quality develop brand perceptions differently from others [22], [19] and influence consumers' purchasing decisions [19]. Perceived quality is one of the dimensions of customer-based brand equity [5], [22] and is supported by several studies [12], [33], [17], [30], [31], [32]. Thus, the hypothesis for perceived quality is formulated:

H2: Perceived quality has a significant direct effect on brand equity of zakat instituion. 


\subsubsection{Brand Association and Brand Equity}

Brand association is also a brand equity dimension and can contribute to brand memory [6]. Studies show that brand associations provide a differential advantage for brands [13]. The brand association can take the form of taking information related to brands, differentiation, providing reasons for purchase, and positive feelings [22]. Aaker's studies have proposed brand association as a brand equity dimension, which researchers further evaluate in various cases [9], [34], [17], [30], [31], [32]. A significant positive brand association will have higher brand equity. Thus, the following hypothesis is formulated:

H3: The brand association has a significant direct effect on brand equity of zakat instituion.

\subsubsection{Brand Loyalty and Brand Equity}

Brand loyalty is a core dimension of brand equity [31]. According to Aaker, brand loyalty is defined as the possibility of customers switching to another brand whenever the product's feature or price has changed [7]. Keller mentions brand loyalty as the relationship between customers and brands and the relationship between customers and brands. Keller also proposes the term 'brand resonance' whereby a customer with a higher level of brand loyalty is found to have a higher brand resonance[27]. Aaker has established brand loyalty as a dimension of brand equity and has been well studied by several researchers in various cases [12], [35], [16], [36], [18], [37], [29], [31], [32]. Thus, the following hypothesis is formulated:

H4: Brand loyalty has a significant direct effect on brand equity of zakat instituion.

\section{Methods}

\subsection{Measuring scale}

Brand equity for zakat institutions in this study is built based on a model developed by Aaker. Likewise, items for brand awareness, perceived quality, brand association, and brand loyalty variables were also adapted from several studies by Aaker [6], Yoo et al. [12], Yasin et al. [29] and Mahfooz [32]. While the items to measure brand equity were adapted from the measurement scale developed by Yoo et al. [12] and Mahfooz [32]. They suggest identifying brand equity from a customer perspective by evaluating current brands with comparable brands in the same category. For the context of zakat institutions, the comparison of zakat institution brands is carried out by comparing one zakat institution to another. A five-point Likert scale was used in this study, ranging from " $1=$ strongly disagree" to " $5=$ strongly agree".

\subsection{Data Collection}

Data were collected by distributing questionnaires. This survey was conducted in Greater Jakarta, where the enormous amount of zakat collected in this area is Indonesia's most extensive. The population of paying zakat is the largest compared to other regions in Indonesia. The zakat institution brand being measured is the Dompet Dhuafa brand, where it has been operating for 26 years. Besides, Dompet Dhuafa is diligent in conducting brand campaigns in various media. The sampling technique was clustered random sampling in which 
the questionnaires were distributed in five Greater Jakarta areas. The questionnaires were distributed over 500 questionnaires, of which 375 responses are valid for analysis purposes (response rate 70 percent). The questionnaire's first question is, where do they pay zakat, followed by a series of items related to brand equity dimensions.

\section{Result}

\subsection{Respondent Profile}

This section will present respondents' profiles, including gender, age, education, and frequency of paying zakat in a year. Of the 375 respondents, 211 (56.27 percent) were male, and 164 (43.73 percent were female). The age group of zakat payers is dominated by the age group 17-25 years (37.6 percent), followed by ages $26-35$ years ( 27.73 percent), then $36-45$ years (21.87 percent). Those aged over 45 years only consisted of 48 respondents (12.8 percent). Based on education, zakat payers with Senior High School and Bachelor education dominate with a percentage of 37.33 percent and 33.6 percent, respectively. Then, most of the zakat payers pay their zakat a majority of 1-2 times in a year, with 68.27 percent followed by a frequency of 3-4 times in a year. For more details, see Table 1

Table 1. Respondent Profile

\begin{tabular}{llrr}
\hline Variable & Category & Frequency & Percentage \\
\hline Gender & Male & 211 & 56.27 \\
& Female & 164 & 43.73 \\
Age & $17-25$ years old & 141 & 37.60 \\
& $26-35$ years old & 104 & 27.73 \\
& $36-45$ years old & 82 & 21.87 \\
Education & upper 45 years old & 48 & 12.80 \\
& Elementary \& Junior High School & 15 & 4.00 \\
& Senior High School & 140 & 37.33 \\
& Diploma & 60 & 16.00 \\
& Bachelor & 126 & 33.60 \\
& Master & 30 & 8.00 \\
Frequency of & Doctor & 4 & 1.07 \\
Paying Zakat & 3 -2 times in a year & 256 & 68.27 \\
in A Year & $5-6$ times in a year & 64 & 17.07 \\
& $7-8$ times in a year & 48 & 12.80 \\
& More than 8 times in a year & 2 & 0.53 \\
& & 5 & 1.33 \\
\hline
\end{tabular}

\subsection{Evaluation of Measurement Model (Outer Model)}

The processing process uses SMART PLS 3.0 software to test several Structural Equation Modeling (SEM) procedures. Convergent validity aims to determine the validity of the relationship between the indicator and its latent variable. Convergent validity is known based on the loading factor value. An instrument meets the convergent validity test if it has a loading factor value above 0.7 [38]. The test results indicate that all indicators measuring brand awareness, perceived quality, brand association, brand loyalty, and brand equity have a greater value than 0.7. Thus the indicator is declared valid. For more details, see Figure 2. 


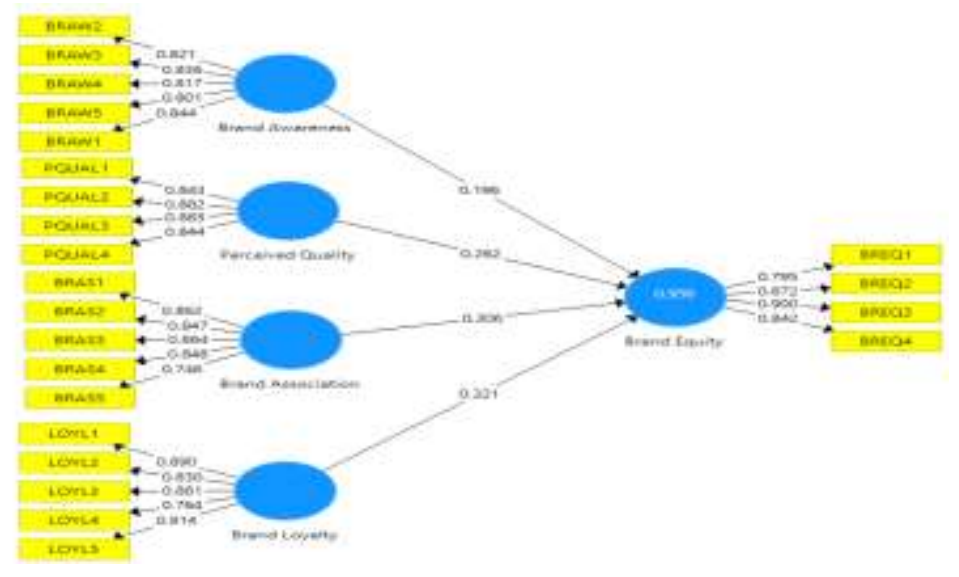

Fig. 2. Result of PLS-SEM Calculation.

The calculation of construct reliability used discriminant reliability (AVE), Cronbach's alpha and composite reliability. The calculation results appear in Table 2 below:

Table 2. The results of the calculation of AVE, composite reliability, and Cronbach's Alpha

\begin{tabular}{lcrc}
\hline \multicolumn{1}{c}{ Variable } & $\begin{array}{c}\text { Average Variance } \\
\text { Extracted (AVE) }\end{array}$ & $\begin{array}{l}\text { Composite } \\
\text { Reliability }\end{array}$ & Cronbach Alpha \\
\hline Brand Awarenss & 0.679 & 0.914 & 0.882 \\
Perceived Quality & 0.746 & 0.922 & 0.886 \\
Brand Association & 0.696 & 0.920 & 0.890 \\
Brand Loyalty & 0.701 & 0.921 & 0.893 \\
Brand Equity & 0.728 & 0.914 & 0.875 \\
& & & \\
\hline
\end{tabular}

The test criteria state that if the discriminant reliability indicated by AVE is greater than 0.5 , Cronbach alpha is greater than 0.7 , and the composite reliability is greater than 0.7 , then the construct is declared reliable[39]. Overall, using the calculation of AVE, composite reliability, and Cronbach's alpha, it can be concluded that all instrument items that measure variables are declared reliable.

\subsection{Evaluation of Measurement Model (Outer Model)}

Structural model evaluation describes the relationship between latent variables in the substantive theory. In this study, the PLS structural model was tested by measuring the value of $\mathrm{R}^{2}$ (goodness of fit model). The path model in this study is also used to determine the level of influence of hypothesis testing.

The $\mathrm{R}^{2}$ in this study was 0.956 or $95.6 \%$. This results can shows that the overall model of $95.6 \%$ can explain the diversity of brand equity variables or, in other words, the contribution of brand awareness, perceived quality, brand association, and brand loyalty to brand equity as 
a whole is $95.6 \%$. In comparison, the remaining $4.4 \%$ contributes to other variables that do not discuss in this study.

This study also uses the t-test for the direct effect of the independent variable on the dependent variable. The direct effect test in this study is used to explain the hypotheses H1, $\mathrm{H} 2, \mathrm{H} 3$, and H4. The test criteria are using the t-count value. The independent variable (exogenous) has a significant effect if the t-statistics value is greater than the t-table with the $\mathrm{t}$ table limit $=1.96$ [40]. Based on the t-count value, $\mathrm{H} 1$ is accepted, where brand awareness has a significant effect on brand equity with t-statistics of 8,594. The effect of perceived quality on brand equity is significant with t-statistics of 11,674 , which is greater than t-table $=1.96$. These results indicate that $\mathrm{H} 2$ is accepted; that is, perceived quality significantly affects brand equity. The test results also show that brand association significantly affects brand equity with t-statistics of 11,973 greater than t-table $=1.96$. These results indicate that H3 is accepted; namely, the brand association significantly affects brand equity. For the brand loyalty variable, hypothesis testing results are based on the t-statistics value of 19,760, which is greater than ttable $=1.96$. These results indicate that $\mathrm{H} 4$ is accepted; that is, brand loyalty has a significant effect on brand equity. In summary, the results of hypothesis testing can be seen in Table 3 .

Table 3. Hypotheses test results

\begin{tabular}{lrrr}
\hline Exogenous & Endogenous & t-statistics & Results \\
\hline Brand Awarenss & Brand Equity & 8.594 & H1 accepted \\
Perceived Quality & Brand Equity & 11.674 & H2 accepted \\
Brand Association & Brand Equity & 11.973 & H3 accepted \\
Brand Loyalty & Brand Equity & 19.760 & H4 accepted \\
\hline
\end{tabular}

\section{Discussion and Conclusions}

The results of this study indicated that Aaker's four brand equity dimensions have a significant positive relationship with overall brand equity[6]. It is also in line with several other studies for various cases. In this study, the zakat institution can apply the brand equity concept to enhance zakat fundraising. These findings confirm that increased brand awareness, perceived quality, brand association, and brand loyalty increase overall brand equity. In the context of zakat institutions, the institution's high brand equity will encourage zakat payers to donate their zakat in the institution.

If viewed per variable, the antecedent with a significant contribution to brand equity is the variable brand loyalty with $\beta=0.321$, followed by brand association $(\beta=0.306)$. This result is following previous research conducted by Yoo [12], Atilgan et al.[16], Yasin et al. [29], Gil et al. [37], Buil et al. [25] and Mahfooz [32]. This finding implies that zakat institutions should focus on building brand loyalty to generate a higher level of brand equity overall.

Within the conceptual framework, all hypotheses have a significant positive relationship for the institutional brand of zakat. This framework of study provides a better understanding of the concept of brand equity for zakat institutions and zakat management as a whole. This study offers an overview of the antecedents and implications of brand equity, which will help 
the management of zakat institutions better understand the factors influencing brand equity and guide them to establish effective fundraising strategies to raise more zakat than before.

\section{Limitation and Future Research}

The main limitation of this study is that sampling is limited to the Greater Jakarta area. Samples from these regions can limit generalizations to all Indonesia countries, which have a wide geographical area. The study could be extended to areas outside Greater Jakarta, such as Java, Sumatra, Borneo, and Sulawesi. The research model can also be further developed by adding several variables, such as brand trust, brand preference, and brand performance. Brand equity can also be applied to other non-profit organizations apart from zakat institutions such as charities, environmental NGOs, and other non-profit organizations.

\section{References}

[1] BAZNAS, Statistik Zakat Nasional 2017. Jakarta: Badan Amil Zakat Nasional, 2018.

[2] Widarwati, E., Afif, N. C., and Zazim, M., "Strategic Approcah for Optimizing of Zakah Institution Performance: Customer Relationship Management," Al-Iqtishad J. Islam. Econ., vol. 9, no. 1, pp. 81-94, (2016).

[3] Cobb-Walgren, C. J., Ruble, C. A., and Donthu, N., "Brand equity, brand preference, and purchase intent," J. Advert., vol. 24, no. 3, pp. 25-40, (1995).

[4] Broyles, S. A., Schumann, D. W. and Leingpibul, T., "Examining brand equity antecedent/consequence relationships," J. Mark. Theory Pract., vol. 17, no. 2, pp. 145-162, (2009).

[5] Farquhar, P. H., "Managing Brand . Peter Farquhar,” Mark. resesearch, no. September, pp. 2433, (1989).

[6] Aaker, D. A., Managing Brand Equity: Capitalizing on the Value of A Brand Name. New York: The Free Press, (1991).

[7] Aaker, D. A., Brand Relevance: Making Competitors Irrelevant. San Francisco: Jossey-Bass, (2011).

[8] Keller, K. L., Strategic Brand Management: Building, Measuring and Managing Brand Equity. New Jersey: Pearson Education Limited, (2013).

[9] Yoo, B., and Donthu, N., "Developing and validating a multidimensional consumer-based brand equity scale,” J. Bus. Res., vol. 52, no. 1, pp. 1-14, (2001).

[10] Keller, K. L., "Conceptializing, Measuring, and Managing Customer-Based Brand Equity,” Am. Mark. Assoc., vol. 57, no. 1, pp. 1-22, (1993).

[11] Cheng-Hsui Chen, A., "Using free association to examine the relationship between the characteristics of brand associations and brand equity," J. Prod. Brand Manag., vol. 10, no. 7, pp. 439-451, (2001).

[12] Yoo, B., and Donthu, N., "Testing cross-cultural invariance of the brand equity creation process," J. Prod. Brand Manag., vol. 11, no. 6, pp. 380-398, (2002).

[13] Vázquez, R., del Río, A. B., and Iglesias, V., "Consumer-based Brand Equity: Development and Validation of a Measurement Instrument," J. Mark. Manag., vol. 18, no. 1-2, pp. 27-48, (2002).

[14] Washburn, J. H., and Plank, R. E., "Measuring Brand Equity: An Evaluation of a ConsumerBased Brand Equity Scale," J. Mark. Theory Pract., vol. 10, no. 1, pp. 46-62, (2002).

[15] Keller, K. L., "Understanding brands, branding and brand equity," Interact. Mark., vol. 5, no. 1, pp. 7-20, (2003).

[16] Atilgan, E., Aksoy, S., and Akinci, S., "Determinants of the brand equity: A verification approach in the beverage industry in Turkey," Mark. Intell. Plan., vol. 23, no. 3, pp. 237-248, (2005).

[17] Pappu, R., Quester, P. G., and Cooksey, R. W., "Consumer-based brand equity and country-oforigin relationships: Some empirical evidence," European Journal of Marketing, vol. 40, no. 5- 
6. pp. 696-717, (2006).

[18] Pappu, R., and Quester, P., "Does customer satisfaction lead to improved brand equity An empirical examination of two categories of retail brands," J. Prod. Brand Manag., vol. 15, no. 1, pp. 4-14, (2006).

[19] Ha, H. Y., Janda, S., and Muthaly, S., "Development of brand equity: Evaluation of four alternative models," Serv. Ind. J., vol. 30, no. 6, pp. 911-928, (2010).

[20] Liu, M. T., Wong, I. K. A., Tseng, T. H., Chang, A. W. Y., and Phau, I., “Applying consumerbased brand equity in luxury hotel branding," J. Bus. Res., vol. 81, no. June, pp. 192-202, (2017).

[21] Shimp, T.A. and Andrews, J.C., Advertising, Promotion, and Other Aspects of Integrated Marketing Communications, 13th ed. Mason: Cengage Learning, (2013).

[22] Aaker, D. A., "Measuring Brand Equity Across Products and Markets," Calif. Manage. Rev., vol. 38, no. 3, pp. 102-120, (1996).

[23] Zeithaml, V. A., "Consumer Perceptions of Price, Qualitye," J. Mark., vol. 52, no. 3, pp. 2-22, (1988).

[24] Keller K. L., and Brexendorf, T. O., "Measuring Brand Equity,”, pp. 1409-1439 (2019).

[25] Buil, I., Martínez, E., and de Chernatony, L., "The influence of brand equity on consumer responses," J. Consum. Mark., vol. 30, no. 1, pp. 62-74, (2013).

[26] Aaker, D. A., "Managing The Most Important Asset: Brand Equity," Plan. Rev., vol. 20, no. 5, pp. 56-58, (2006).

[27] Keller, K. L., "Strategic Brand Management 4th Edition Keller." (2011).

[28] Bojei, J., and Hoo, W. C., "Brand equity and current use as the new horizon for repurchase intention of smartphone," Int. J. Bus. Soc., vol. 13, no. 1, pp. 33-48, (2012).

[29] Yasin, M. N., Noor, M. N. and Mohamad, O., "Does image of country-of-origin matter to brand equity?," J. Prod. Brand Manag., vol. 16, no. 1, pp. 38-48, (2007).

[30] Tong, X. and Hawley, J. M., "Measuring Customer Based Brand Equity: Empirical Evidence from the Sportswear Market in China," J. Prod. Brand Manag., vol. 18, no. 4, pp. 262-271, (2009).

[31] Kumar, R. S., Dash, S. and Purwar, P. C., "The nature and antecedents of brand equity and its dimensions," Mark. Intell. Plan., vol. 31, no. 2, pp. 141-159, (2013).

[32] Mahfooz, Y., "Brand Equity-Consequence Relationship : Evidence from Automobile Industry," Int. J. Bus. Manag., vol. 10, no. September, pp. 81-90, (2015).

[33] Netemeyer, R. G., "Developing and validating measures of facets of customer-based brand equity," J. Bus. Res., vol. 57, no. 2, pp. 209-224, (2004).

[34] Ye, G. and Van Raaij, W. F., "Brand equity: Extending brand awareness and liking with signal detection theory," J. Mark. Commun., vol. 10, no. 2, pp. 95-114, (2004).

[35] Chaudhuri A., and Holbrook, M. B. "The chain of effects from brand trust and brand affect to brand performance: The role of brand loyalty," J. Mark., vol. 65, no. 2, pp. 81-93, (2001).

[36] Delgado-Ballester, E., and Munuera-Alemán, J. L., "Does brand trust matter to brand equity?," J. Prod. Brand Manag., vol. 14, no. 3, pp. 187-196, (2005).

[37] Gil, R. B., Andrés, E. F., and Salinas, E. M., "Family as a source of consumer-based brand equity," J. Prod. Brand Manag., vol. 16, no. 3, pp. 188-199, (2007).

[38] Hair, J. F., Ringle, C. M., and Sarstedt, M., "PLS-SEM: Indeed a silver bullet," J. Mark. Theory Pract., vol. 19, no. 2, pp. 139-152, (2011).

[39] Hair, J. F., Hult, G. T. M., Ringle, C. M., and Sarstedt, M., A Primer on Partial Least Squares Structural Equation Modeling (PLS-SEM). California: SAGE Publications, Inc., (2014).

[40] Hair, J. F., Black, W. C., Babin, B. J., and Anderson, R. E., Multivariate Data Analysis, 7th ed., vol. 0. New Jersey: Prentice Hall, (2010). 